\title{
The peptide motif of the single dominantly expressed class I molecule of the chicken MHC can explain the response to a molecular defined vaccine of infectious bursal disease virus (IBDV)
}

\author{
Colin Butter • Karen Staines • Andrew van Hateren • \\ T. Fred Davison • Jim Kaufman
}

Received: 16 January 2013 / Accepted: 17 April 2013 /Published online: 5 May 2013

(C) The Author(s) 2013. This article is published with open access at Springerlink.com

\begin{abstract}
In contrast to typical mammals, the chicken MHC (the BF-BL region of the B locus) has strong genetic associations with resistance and susceptibility to infectious pathogens as well as responses to vaccines. We have shown that the chicken MHC encodes a single dominantly expressed class I molecule whose peptide-binding motifs can determine resistance to viral pathogens, such as Rous sarcoma virus and Marek's disease virus. In this report, we examine the response to a molecular defined vaccine, fp-IBD1, which consists of a fowlpox virus vector carrying the VP2 gene of infectious bursal disease virus (IBDV) fused with $\beta$ -
\end{abstract}

C. Butter $\cdot$ K. Staines · A. van Hateren - T. F. Davison •

J. Kaufman

Institute for Animal Health, Compton,

Reading, Berkshire RG20 7NN, UK

C. Butter $\cdot$ K. Staines

The Pirbright Institute, Compton Laboratory,

Compton RG20 7NN, UK

\section{A. van Hateren}

Institute for Life Science, University of Southampton,

Building 85, M55,

Southampton SO17 1BJ, UK

J. Kaufman $(\bowtie)$

Department of Pathology, University of Cambridge,

Tennis Court Road,

Cambridge CB2 1QP, UK

e-mail: jfk31@cam.ac.uk

\section{J. Kaufman}

Department of Veterinary Medicine, University of Cambridge,

Madingley Road,

Cambridge CB3 0ES, UK galactosidase. We vaccinated parental lines and two backcross families with fp-IBD1, challenged with the virulent IBDV strain F52/70, and measured damage to the bursa. We found that the MHC haplotype B15 from line 15I confers no protection, whereas $\mathrm{B} 2$ from line $6_{1}$ and $\mathrm{B} 12$ from line $\mathrm{C}$ determine protection, although another locus from line $6_{1}$ was also important. Using our peptide motifs, we found that many more peptides from VP2 were predicted to bind to the dominantly expressed class I molecule BF2*1201 than $\mathrm{BF} 2 * 1501$. Moreover, most of the peptides predicted to bind $\mathrm{BF} 2 * 1201$ did in fact bind, while none bound $\mathrm{BF} 2 * 1501$. Using peptide vaccination, we identified one B12 peptide that conferred protection to challenge, as assessed by bursal damage and viremia. Thus, we show the strong genetic association of the chicken MHC to a T cell vaccine can be explained by peptide presentation by the single dominantly expressed class I molecule.

Keywords Gumboro disease - Avian MHC · T cell epitope · Fowlpox virus vaccine

\section{Introduction}

The MHC is the region with the most disease associations in the human genome, but by far the greatest number and strongest associations are with autoimmune diseases. In contrast, the chicken MHC has many associations with resistance and susceptibility to infectious disease (reviewed in Kaufman 2008). The chance discovery that a single classical class I and a single classical class II molecule are expressed at high levels in common chicken MHC 
haplotypes led us to propose the hypothesis that the BF-BL region of the chicken is a "minimal essential MHC". By this, we meant the region responsible for the major histocompatibility reactions that contains single dominantly expressed classical class I and II molecules whose properties determine the immune response (Kaufman et al. 1995). At the time of this proposal, we also found that there were actually two class I genes with at least one TAP gene in between, which led us to propose that co-evolution with the antigen-presenting genes was responsible for the dominantly expressed class I gene (Kaufman et al. 1995). Since that time, much evidence has been collected to support these views (Jacob et al. 2000; Kaufman et al. 1999a; Koch et al. 2007; Salomonsen et al. 2003; Shaw et al. 2007; Walker et al. 2011; Wallny et al. 2006); including the fact that many if not most nonmammalian vertebrates (as well as at least one marsupial, Belov et al. 2007) have these salient features of the chicken MHC, including the strong associations of the MHC with infectious disease (Grimholt et al. 2003; reviewed in Kaufman 1999, 2008, 2010).

However, there is some confusion in the literature over whether the chicken MHC really is small and simple or is actually large and complicated. Many investigators, including ourselves, have characterised genes located on the chicken MHC microchromosome that in other animals are found in regions of the MHC, adjacent to the MHC, or in MHC paralogous regions (Afanassieff et al. 2001; Briles et al. 1993; Guillemot et al. 1988; Kaufman et al. 1999a; Maruoka et al. 2005; Miller et al. 1994a, b, 1996, 2005; Rogers et al. 2005; Rogers and Kaufman 2008; Ruby et al. 2005; Salomonsen et al. 2003, 2005; Shiina et al. 2007). This has led to an alternative view that the chicken MHC is in fact very large and complex, containing many genes located in at least two separate regions, called MHC-B and MHC-Y (Afanassieff et al. 2001; Delany et al. 2009; Miller et al. 1996; Solinhac et al. 2010). We have concluded that the difference in these views lies in emphasis (Kaufman et al. 1999b). The minimal essential MHC concept as originally stated (Kaufman et al. 1995, 1999a) defines an MHC based on function, a region of the genome containing the classical polymorphic class I and class II genes responsible for strong histocompatibility reactions (that is, a major histocompatibility complex). The alternative view defines the MHC as a genomic region, with any gene ever found in or adjacent to an MHC becoming part of that MHC, and with the term itself becoming a genetic acronym rather than a functional definition. In our view, the minimal essential MHC is the selected and conserved unit of classical MHC molecules (which we call "the classical MHC" and which has also been dubbed "the core MHC",
Shiina et al. 2007), around which other genes come and go as part of the MHC syntenic region (which has also been referred to as "the extended MHC").

Whichever way one wishes to view the chicken MHC, there is no doubt that there is a small and simple region (the BF-BL region) which contains the essential polymorphic components of antigen presentation by classical MHC molecules, and that this close proximity of classical MHC genes with the polymorphic genes that process and load their peptides is a feature of many, if not most, non-mammalian vertebrates. It therefore remains interesting and important to test to what extent the single dominantly expressed MHC molecules of the chicken MHC can explain the strong genetic associations with disease resistance and vaccine responses.

We have determined simple peptide motifs for certain chicken class I molecules based on the peptides eluted from chicken class I molecules isolated from spleen and blood cells (Kaufman et al. 1995; Koch et al. 2007; Wallny et al. 2006). There are strong MHC associations for resistance and susceptibility to the pathogens Rous sarcoma virus (RSV) and Marek's disease virus (MDV), and we found many more peptides predicted to bind class I molecules from resistant than from susceptible chicken lines. We used cell binding and assembly assays to determine which of the peptides predicted by the simple motifs would actually bind the class I molecules. For RSV, we found that vaccination with a single identified peptide would eliminate disease (Hofmann et al. 2003). Since then, the utility of these motifs has been confirmed by other researchers for the pathogen avian influenza virus (Hou et al. 2012; Reemers et al. 2012). In this paper, we wish to examine a poultry vaccine.

Gumburo disease is caused by an immunosuppressive birnavirus called infectious bursal disease virus (IBDV) that infects and kills cells of the B lineage in chickens (reviewed in Ingrao et al. 2013; Mahgoub et al. 2012; Müller et al. 2003, 2012; Schat and Skinner 2008; van den Berg 2000). There is biphasic age-related resistance. Chicks up to 2 weeks old frequently survive, although the bursa is ravaged, the B cell system is depleted, and thereafter birds do not respond well to vaccines. There follows a period of susceptibility, peaking at 3-4 weeks of age, during which a virulent virus will kill birds. With time, an increasing resistance to mortality develops, although the birds may still suffer immunosuppression and morbidity, evidenced by weight loss or reduction in egglaying. The disease is controlled mainly by vaccination in ovo, vaccination of chicks or vaccination of laying hens, usually with an attenuated live viral vaccine and often followed by an inactivated vaccine, both of which raise antibodies mostly to the major capsid protein, viral protein 2 (VP2). However, both antigenic variation and increases in virulence of the virus have been reported, so Gumboro disease is still an economic concern for the 
poultry industry, and various approaches to vaccines continue to be developed.

An early experimental vaccine called fp-IBD1 was created with the VP2 as a fusion protein with $\beta$-galactosidase in a fowlpox virus vector (Bayliss et al. 1991). This vaccine protects some experimental chicken lines but not others (Shaw and Davison 2000). In particular, line $6_{1}$ (homozygous for MHC haplotype B2) and line C-B12 (homozygous for B12) were shown to be protected by fp-IBD1, while line 15I (homozygous for B15) was not. The protection in line $6_{1}$ was partially conferred by the fowlpox virus vector alone, while the protection in line C-B12 was not. In both cases, the protection was found not to be due to antibodies, which suggested the involvement of $\mathrm{T}$ cells recognising MHC molecules (Shaw and Davison 2000). In this report, we extend this work to examine the contribution of the chicken MHC to protection by the vaccine fp-IBD1.

\section{Materials and methods}

Animals The histories of the chicken lines $6_{1}$ (B2), C-B4 (B4), C-B12 (B12) and 15I (B15), bred and maintained under specific pathogen-free conditions at the Institute for Animal Health (Compton, UK), have been described (Jacob et al. 2000). Chicks were transferred at 1 day of age to isolation accommodation equipped with high-efficiency particle air filters. All procedures were carried out in accordance the United Kingdom Animals (Scientific Procedures) Act and were subject to local ethical review.

Backcross and mapping $\mathrm{F} 1$ crosses were produced between C-B12 and 15I birds and between $6_{1}$ and 15I birds. Laying F1 hens were inseminated with semen from 15I birds to produce backcross progeny. Typing by microsatellite analysis (Khatib et al. 1993) yielded $35 \mathrm{MHC}$ heterozygous and $25 \mathrm{MHC}$ homozygous progeny from the $15 \mathrm{I} \times\left(6_{1} \times 15 \mathrm{I}\right)$ backcross, and $24 \mathrm{MHC}$ heterozygous and 25 MHC homozygous progeny from the $15 \mathrm{I} \times(\mathrm{C}-\mathrm{B} 12 \times 15 \mathrm{I})$ backcross. Together with 30 birds of each parental line, all chicks were vaccinated with fp-IBD1 and challenged with F52/70 as described below.

Fowlpox vectored vaccination The fowlpox virus recombinant vaccine fp-IBD1 encodes the VP2 sequence of the virulent IBVD virus $F 52 / 70$ as a $\beta$-galactosidase fusion protein (Bayliss et al. 1991) and was produced by tissue culture passage on chick embryo fibroblasts as previously described (Shaw and Davidson 2000). Chicks were vaccinated at 1 and 3 weeks of age with $10^{7}$ plaque-forming units fp-IBD1 in a total volume of
$50 \mu \mathrm{l}$. The vaccine was dropped onto a section of the wing web, and the skin punctured 30 times with a 25 -gauge needle. Local inflammation was evident at the site of scarification within 2 days and resolved shortly after.

Challenge virus and infection IBDV F52/70 was propagated in vivo, and the active concentration of virus was assayed to determine egg infectious dose (EID) as previously described (Butter et al. 2003; Van Loon et al. 1994). Chicks were challenged with $10 \mathrm{EID}_{50}$ IBDV F52/70 in a total volume of $100 \mu \mathrm{l}$ by the intranasal route, 10 days after the second vaccination with either peptide (see below) or fp-IBD1 (see above).

Peptide prediction As in Wallny et al. (2006), peptides were predicted from VP2 sequence derived from F52/70 (accession number D00869.2) by using the GCG program FINDPATTERNS (Anonymous 1991) and relaxed motifs for the dominantly expressed class I molecules of two chicken haplotypes. These relaxed motifs allow both octamers and nonamers with all residues found in anchor positions by pool sequencing (Wallny et al. 2006). The motifs are denoted for FINDPATTERNS by the notation $\mathrm{xxx}(\mathrm{x}, \mathrm{xx})(\mathrm{V}, \mathrm{I}) \mathrm{xx}(\mathrm{V}, \mathrm{L}, \mathrm{I})$ for $\mathrm{B} 12$ and $\mathrm{xRxxxx}(\mathrm{x}, \mathrm{xx}) \mathrm{Y}$ for $\mathrm{B} 15$, in which $x$ denotes any amino acid, single capital letters refer to amino acids in the IUPAC single letter code and parentheses enclose alternatives, so $(\mathrm{x}, \mathrm{xx})$ means either one or two amino acids, and (V,L,I) means either valine, leucine or isoleucine. Peptides were synthesized by fluorenylmethoxycarbonyl chemistry, purified by HPLC, and resuspended at $1 \mathrm{mg} / \mathrm{ml}$ in PBS (with up to $1 \%$ DMSO).

Stabilisation assay As in Wallny et al. (2006), chicken peripheral blood lymphocytes without thrombocytes were cultured $\left(10^{7}\right.$ cells per $\mathrm{ml}$ at $\left.40{ }^{\circ} \mathrm{C}, 5 \% \mathrm{CO} 2\right)$ overnight in Dulbecco's modified minimal Eagle's medium with $0.5 \mathrm{mg} / \mathrm{ml}$ bovine serum albumin (BSA) and with or without $1 \mathrm{mM}$ synthetic peptides (in triplicate). Then, cells were washed (phosphate-buffered saline, $0.5 \%$ BSA, $0.1 \%$ $\mathrm{NaN}_{3}$ ), and flow cytometric analysis using a monoclonal antibody against chicken $\beta_{2}$-microglobulin (F21-21, Skjødt et al. 1986) followed by FITC-conjugated goat anti-mouse IgG (Silenus, Paris) was performed, gating on small lymphocytes.

Assembly assay As in Koch et al. (2007), inclusion bodies from $\beta_{2} \mathrm{~m}$ cDNA sequence (encoding the mature protein without a signal sequence but beginning with a start codon for methionine) and for BF2*1201 cDNA (residues 1-270 of the mature protein without a signal sequence but with a codon for Met added at the beginning) in pET22b $(+)$ were isolated from BL21 ( $\lambda$ DE3) pLysS Rosetta cells, and dissolved in $8 \mathrm{M}$ urea, $10 \mathrm{mM} 2$-mercaptoethanol, 
$100 \mathrm{mM} \mathrm{NaH}{ }_{2} \mathrm{PO}_{4}, 10 \mathrm{mM}$ TrisCl, $\mathrm{pH}$ 8. Small-scale assembly assays were carried out at $4{ }^{\circ} \mathrm{C}$ in $1 \mathrm{ml}$ refold buffer [100 mM TrisCl pH 8.2, $400 \mathrm{mM}$ arginine, $0.5 \mathrm{mM}$ oxidized glutathione, $5 \mathrm{mM}$ reduced glutathione, $2 \mathrm{mM}$ ethylenediamine tetraacetic acid, $0.1 \mathrm{mM}$ 4-(2 aminoethyl) benzenesulfonyl fluoride (Pefablock, Sigma)]. The peptide, $\beta_{2} \mathrm{~m}$ and heavy chain were added slowly with vigorous stirring in a molar ratio of 10:2:1 (usually around 1:24:31 $\mu \mathrm{g}$ in $1 \mathrm{ml}$ ). After 18-30 h, FPLC size exclusion chromatography (AKTA, Pharmacia) with a HiLoad 26/60 Superdex 75 column (Pharmacia) in $0.15 \mathrm{M} \mathrm{NaCl}, 0.1 \mathrm{M}$ TrisCl pH 8.2 was used to separate aggregates, monomers, heavy chains, $\beta_{2} \mathrm{~m}$, peptides and smaller molecules.

Peptide vaccination As in Hofmann et al. (2003), $18 \mathrm{mg}$ L- $\alpha$-phosphatidylcholine, 2 mg L- $\alpha$-phosphatidyl-DL-glycerol and $5 \mathrm{mg}$ cholesterol (all components from Sigma) were suspended in $5 \mathrm{ml}$ chloroform and rotary evaporated under reduced pressure until a thin lipid film formed on the flask wall. Residual chloroform was removed by vacuum desiccation. Three milligrams of peptide was dissolved in $1 \mathrm{ml}$ PBS containing $0.4 \mathrm{mg}$ Quil A and $1 \mathrm{mM}$ 2-mercaptoethanol. This solution was added to the dried lipids and slowly shaken until the lipids were re-suspended and then equilibrated $30 \mathrm{~min}$ at room temperature. C-B12 chicks were immunised at 1 and 3 weeks of age with $100 \mu \mathrm{g}$ peptide in $0.2 \mathrm{ml}$ of liposomes per injection, i.m. into the pectoral muscle. Some other chicks were not vaccinated, some others were vaccinated with fpIBD1 and most chicks were challenged with F52/70 as described above. Three were ten birds per group. Blood samples were taken daily to determine viremia (Moody et al. 2000). Five days post-infection, the birds were sacrificed, the bursa dissected, RNA extracted by standard techniques (Staines et al. 2013) and the remaining tissue prepared for routine waxembedded histology.

Assessment of protection Bursal/body weight ratio, bursal damage score, peak blood viremia and bursal viral load were used as post-mortem measures of pathology. Bursal damage score is described elsewhere (Williams and Davison 2010). Briefly, a histological scoring system ranging from 0 , representing normal bursal architecture, to 5, representing complete loss of bursal architecture, was used to assess bursal histopathology. All slides were encoded and the scoring carried out blind, with the identity of the samples unknown. Quantitative RT-PCR was performed to determine relative amounts of VP2 gene transcripts in blood and bursal samples using the primer-probe combinations previously described (Moody et al. 2000) and the results normalised against the expression of $28 \mathrm{~S}$ RNA, determined in a duplex reaction with VP2, and presented as $\log _{2} R_{\text {o }}$ (Butter et al. 2007).

\section{Results}

Genetic mapping shows that the chicken MHC is a major locus for response to fp-IBD1

Given that fp-IBD1 elicits very different levels of protection in different strains of chicken, we examined whether the MHC is a major genetic locus in this response. Using the high responder lines (line 61 homozygous for MHC haplotype B2, C-B12 homozygous for B12) and a low responder line (15I homozygous for B15), we first bred $\mathrm{F} 1$ chickens $(6 \times 15$ I heterozygous for B2/B15, and C-B12 $\times 15$ I heterozygous for B12/B15), then bred two backcross families, immunised with fp-IBD1, challenged with the virulent IBDV strain F52/70, and measured damage to the bursa of Fabricius.

In the first comparison (Fig. 1), the majority of the chickens of the low responder parental line 15I (B15/B15) had a high bursal damage score, while nearly all of the chickens of the high responder parental line $6_{1}$ (B2/B2) had little or no bursal damage. From the backcross $15 \mathrm{I} \times \mathrm{F} 1\left(6_{1} \times 15 \mathrm{I}\right)$ family, about one quarter of the birds had a high bursal damage score, and the rest had little or no damage. After typing these chickens, we found that nearly all of the B15/B2 heterozygotes had little or no damage, but that half of the B15/B15 homozygotes had little damage and the other half had a high bursal damage score. Since genes outside of the MHC should have segregated randomly, this shows that a single B2 haplotype in a B2/B15 heterozygote chicken confers protection, which was as much as two B2 haplotypes in a B2/B2 homozygote chicken. However, there must be another gene outside of the MHC which confers responsiveness as well since half of the B15/B15 homozygote chickens were protected. Thus, there are two genetic loci that confer the responsiveness found in line $6_{1}$ chickens.

In the second comparison (Fig. 1), the majority of the chickens of the low responder parental line 15I (B15/B15) had a high bursal damage score, while the majority of the high responder parental line C-B12 (B12/B12) had little or no bursal damage. From the backcross $15 \mathrm{I} \times \mathrm{F} 1(\mathrm{C}-\mathrm{B} 12 \times 15 \mathrm{I})$ family, about half of the birds had a high bursal damage score, while half had less damage. After typing these chickens, we found that most of the B15/B15 homozygote chickens had high bursal damage score, but most of the B12/B15 heterozygote chickens had a moderate bursal damage score. Since genes outside of the MHC should have segregated randomly, this shows that a single B12 haplotype in a B12/B15 heterozygote chicken confers about half as much protection as two B12 haplotypes in a B12/B12 homozygote chicken. Thus, there is one major 


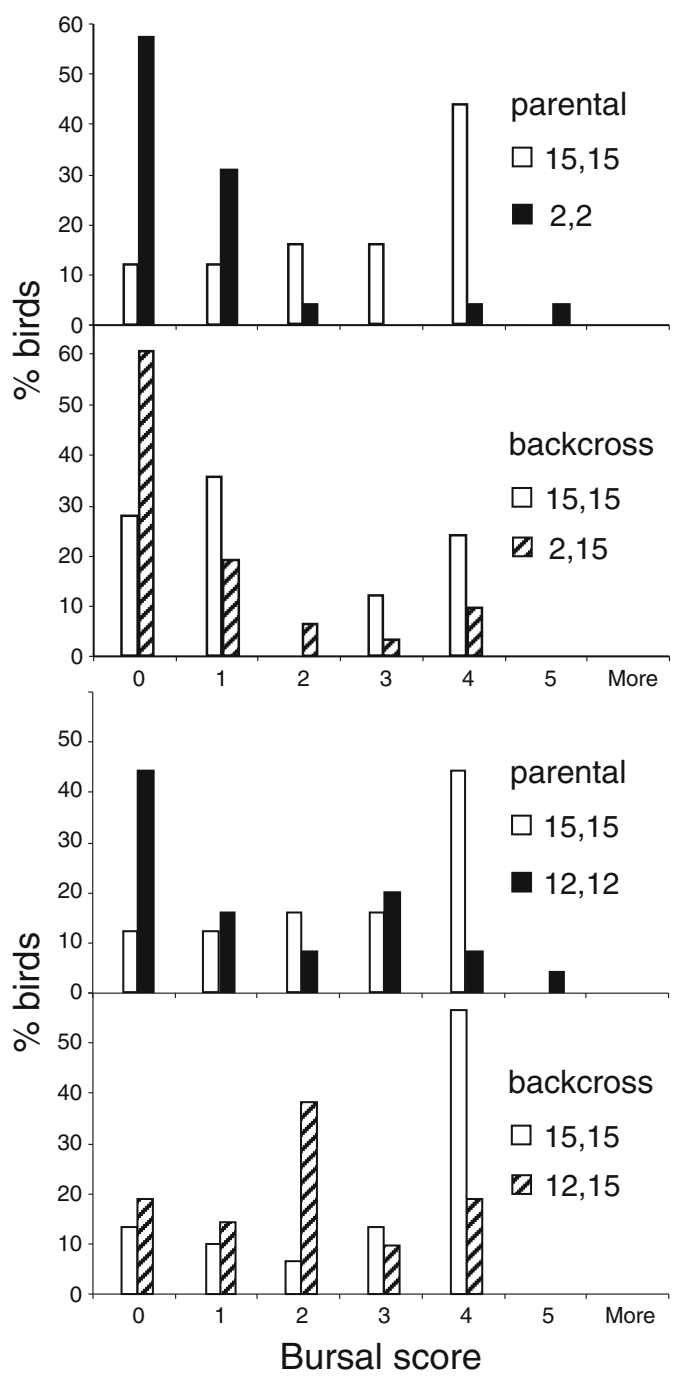

Fig. 1 Backcross mapping of protection conferred by fp-IBD1 vaccination to bursal damage by IBDV strain F52/70 challenge in two families derived from line 6 (MHC haplotype B2), CB-12 (B12) and 15I (B15). The graphs represent bursal damages score, with 0 as no perceptible damage and 5 as extremely damaged ( $x$-axis) against percentage birds with that score ( $y$-axis). Upper two panels are birds from the parental lines $15 \mathrm{I}$ and $6_{1}$, and birds from the backcross family $15 \mathrm{I} \times$ F1 $\left(15 \mathrm{I} \times 6_{1}\right)$ segregated into the homozygotes and heterozygotes. Lower two panels are birds from the parental lines 15I and C-B12, and birds from the backcross family $15 \mathrm{I} \times \mathrm{F} 1(15 \mathrm{I} \times \mathrm{C}$-B 12$)$ segregated into the homozygotes and heterozygotes

genetic locus that confers responsiveness found in line C-B12 chickens which is the MHC, but two copies of the C-B12 haplotype are necessary for the highest level of protection under these circumstances.

Binding and assembly assays show that the MHCdetermined response to fp-IBD1 correlates with the peptides predicted to bind the MHC class I molecule

Given that the fp-IBD1 vaccine contains IBDV VP2 protein as a fusion protein with $\beta$-galactosidase and that the mechanism of protection does not involve antibodies, it seemed most likely that the response was directed against peptides presented by class I molecules. Having determined peptide motifs for the class I molecules of the B12 and B15 haplotypes (BF2*1201 and the $\mathrm{BF} 2 * 1501)$, we used these motifs to predict peptides from the VP2 protein sequence that might bind these class I molecules. We found 12 peptides that fit the B12 peptide motif, but only 2 peptides that fit the B15 peptide motif (Fig. 2).

From work on mammals (and our own work with these same chicken class I molecules in a previous study), generally only a fraction of peptides that fit the simple kind of motif used here actually bind the class I molecule with measurable affinity. So, we tested the binding of synthetic peptides to chicken peripheral blood lymphocytes with an assay we have used previously (Wallny et al. 2006), a flow cytometry-based class I stabilisation assay analogous in procedure to the RMA-S and T2 stabilization assays using mammalian cells with defective TAP genes. As assessed by the fluorescence in comparison with no peptide controls, neither of the two B15 peptides predicted bound to B15 cells, whereas many of the predicted B12 peptides did bind (Fig. 2).

In addition, we tested the B12 peptides by an assembly assay, in which B12 heavy chain and $\beta_{2} \mathrm{~m}$ were renatured in the presence of peptide, and the material analysed by size exclusion chromatography, as illustrated in Fig. 3. Since the amount of $\beta_{2} \mathrm{~m}$ in the assay was far in excess, ratio of the areas under the peaks of monomer was taken as a measure of the success of the assembly of heavy chain and $\beta_{2}$ m dependent on peptide. Ten of the 12 predicted B12 peptides supported assembly very well, in agreement with the stabilisation assay (Fig. 2).

Immunisation and challenge show that a peptide from fp-IBD1 that binds the MHC class I molecule can confer resistance to IBDV

Having found many peptides from the vaccine fp-IBD1 that bind $\mathrm{BF} 2 * 1201$, the dominantly expressed class I molecule from the B12 haplotype, we wanted to test whether immunisation of C-B12 chickens with one of them would protect against challenge by IBDV. We had previously developed a peptide immunisation protocol that protected against tumour progression after infection of chickens by Rous sarcoma virus. We used the same protocol of intramuscular injection of liposomes loaded with Quil A and various peptides, in comparison with no immunisation and with fp-IBD1 immunisation. Three days after challenge with IBDV strain F52/70, we measured bursal/body weight ratio, bursal damage score, peak blood viremia and bursal viral load (Figs. 4 and 5).

As expected, without the challenge infection, chickens had a normal bursa to body weight ratio, a low bursal 


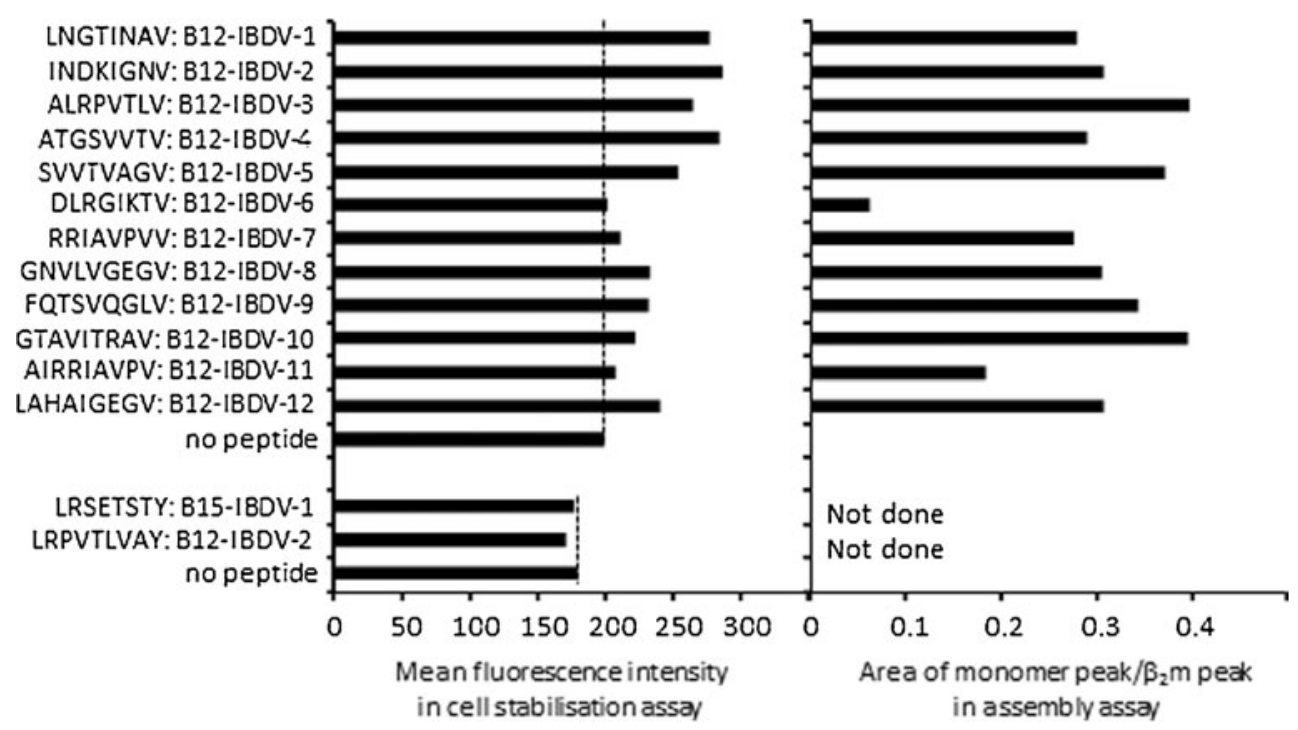

Fig. 2 Cell binding and assembly analysis of VP2 peptides predicted to bind $\mathrm{B} 12$ and $\mathrm{B} 15$ class I molecules. Left hand panel, mean fluorescence intensities measuring the increase of F21-21 binding to cells after culture overnight with $1 \mathrm{mM}$ peptide compared to culture overnight without added peptide. Dotted lines indicate the mean

damage score and no virus in the blood or bursa. All four measures rose after infection without vaccination, as well as after vaccination with two peptides, the control peptide from RSV (RSV6) and one of the peptides from fp-IBD1 (IBDV12). In contrast, protection was evident by all

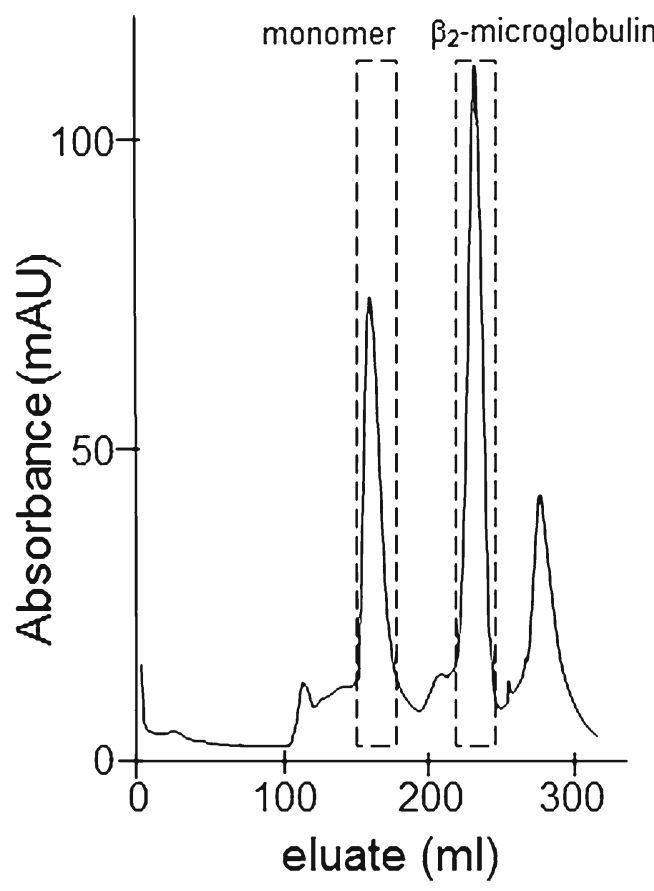

Fig. 3 An example of an assembly assay. Class I heavy chain was renatured with $\beta_{2} \mathrm{~m}$ and peptide IBDV-8, the components separated by size exclusion chromatography, and the areas under the peaks corresponding to reassembled monomer and free $\beta_{2} \mathrm{~m}$ (labelled and indicated by dashed boxes) determined fluorescence intensities of the cells without incubation with peptides. Samples were analysed in triplicate, with standard errors well below $10 \%$. Right hand panel, ratio of the area of peaks corresponding to assembled monomer compared to $\beta_{2} \mathrm{~m}$ from size exclusion chromatography of renaturation assays with indicated peptides

measures after vaccination with fp-IBD1 and even more so after vaccination with another peptide from fp-IBD1 (IBDV8). Thus, immunisation with a peptide from IBDV that binds the dominantly expressed class I molecule $\mathrm{BF} 2 * 1201$ will protect from challenge with a virulent IBDV (Figs. 4 and 5).

\section{Discussion}

In this paper, we have shown that (1) response to a molecular defined vaccine containing the VP2 sequence of IBDV can be determined by at least two genetic loci, one of which is the MHC, (2) absence of VP2 peptides that bind the class I molecule is the basis for the lack of response in a low responder line and (3) presence of at least one VP2 peptide that binds the dominantly expressed class I molecule is the basis for the protection in a high responder line.

The work in this paper grew from earlier observations (Shaw and Davison 2000) that vaccination with fp-IBD1 could protect some experimental chicken lines and not others. Examination of the mechanisms of protection showed that antibody was not involved, which is in accord with the fact that the VP2 protein as a fusion protein with $\beta$-galactosidase in the vaccine is likely to have a different three-dimensional structure compared to VP2 protein as a part of the IBDV capsid. These examinations also showed that line C-B12 was protected by vaccination with fp-IBD1 but not by the fowlpox virus vector alone, while line $6_{1}$ was protected somewhat even by the fowlpox virus vector alone. In contrast, line 15I was not protected. 
The results in our paper fit with these previous results. From genetic mapping, line 15I is a low responder with no protective locus, $\mathrm{C}-\mathrm{B} 12$ is a high responder with only one major protective locus (the MHC) and line $6_{1}$ is a high responder with two major protective loci (the MHC which presumably depends on the VP2 fusion protein, and another locus which may determine response to fowlpox virus vector alone, perhaps through an innate antiviral response like inflammation or natural killer cell responses). From our peptide predictions and peptide vaccination, line $15 \mathrm{I}$ is a low responder because the classical class I molecule BF2*1501 does not bind peptides from the VP2 sequence, while line C-B12 is a high responder because the dominantly expressed class I molecule BF2*1201 finds at least one VP2 peptide (IBDV-8; GNVLVGEGV) that confers
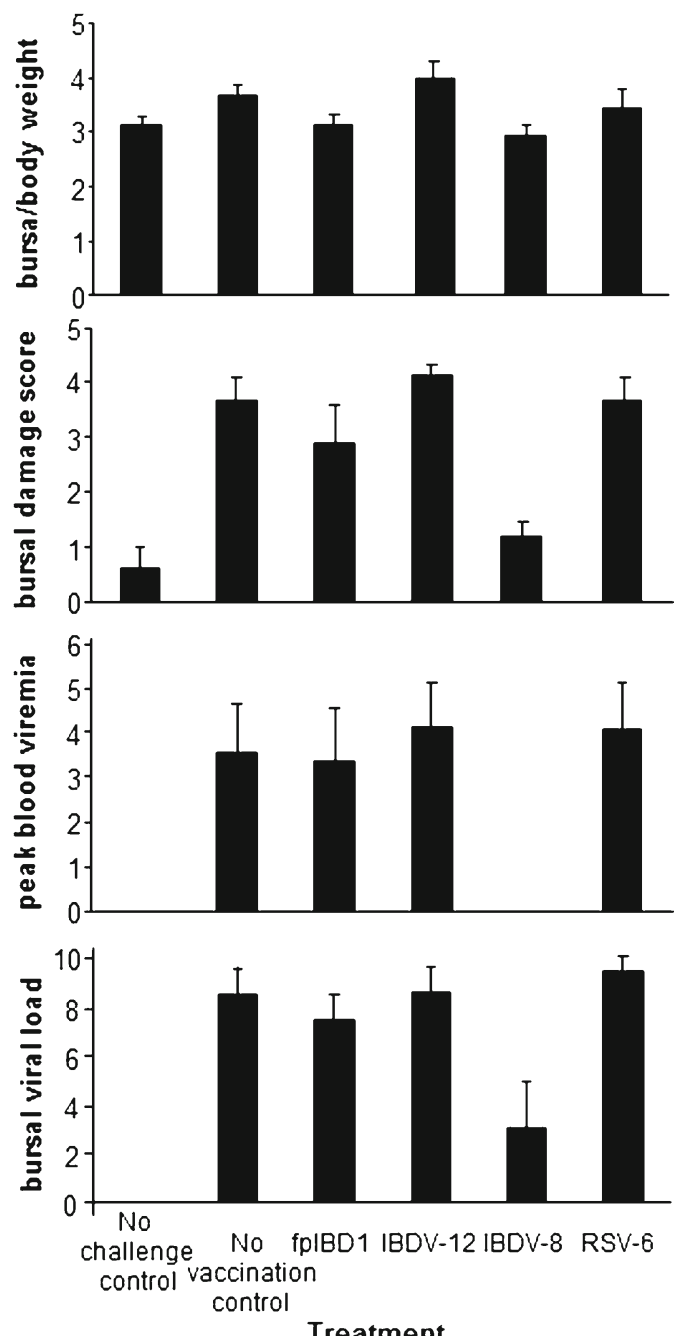

Fig. 4 Means of bursal/body weight ratio $(\times 1,000$; upper panel $)$, bursal damage score (second panel), peak blood viremia $\left(\log _{2} \mathrm{R}_{\mathrm{o}}\right.$; third

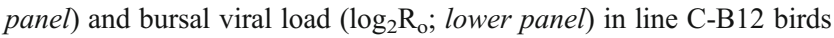
with no challenge, or after IBDV F52/70 challenge following vaccination with nothing, fp-IBD1 or different peptides. As an indication of variability means are shown with their standard errors (though the data do not conform to the strict requirements of parametric analysis)

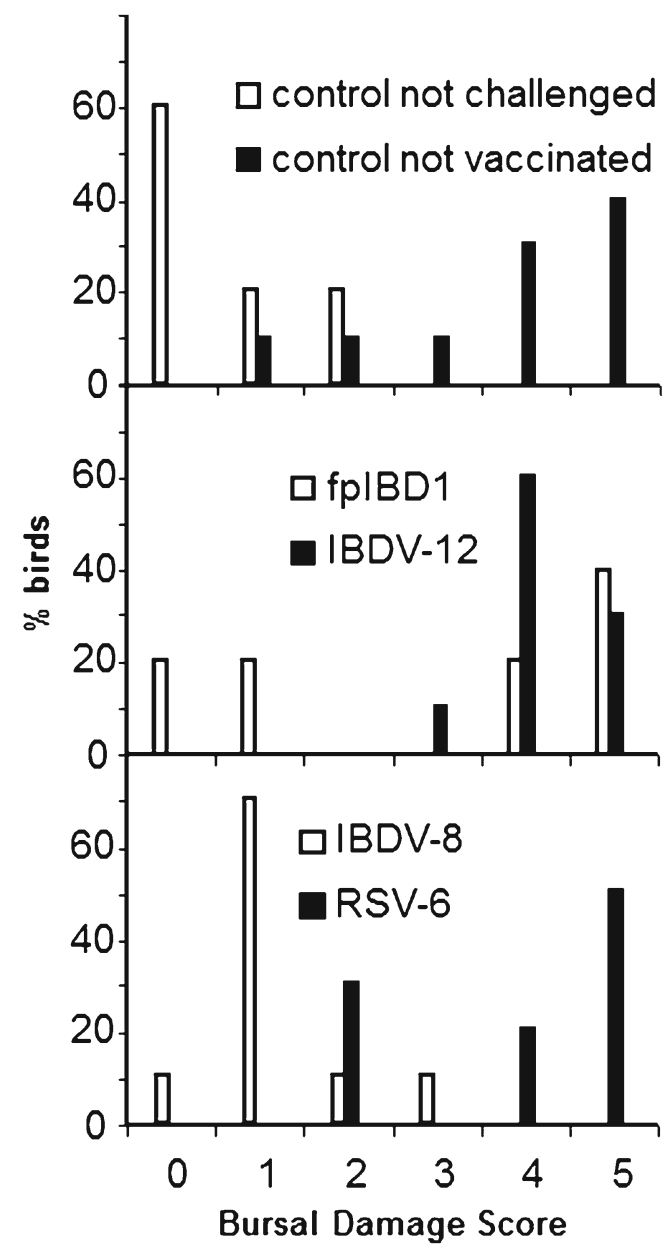

Fig. 5 Percentages of line C-B12 birds with different bursal damage scores after no challenge, or after IBDV F52/70 challenge following vaccination with nothing, fp-IBD1 or different peptides

protection to challenge with a virulent IBDV strain. It must be stressed that IBDV-8 may not be the only peptide that is responsible for protection, but that there is at least one such peptide. On the basis of these results, we would predict (but did not show) that line $6_{1}$ is a responder because the dominantly expressed class I molecule BF2*0201 presents at least one protective IBDV peptide.

Two other interesting points emerged. First, after vaccination with fp-IBD1, the protection of $\mathrm{B} 12 / \mathrm{B} 15$ heterozygotes in the backcross was half of that of B12/B12 homozygotes in the original line. This most likely indicates that the level of peptide bound to BF2*1201 on the surface of cells is a critical factor in priming the immune response (as has been shown for mammals, see for example Bullock et al. 2000), and that the particular conditions of vaccination are just barely sufficient to protect from the particular conditions of challenge. Second, vaccination with the VP2 peptide IBDV-12 (LAHAIGEGV) did not result in a protective immune response after vaccination, despite the fact that this peptide bound well to $\mathrm{BF} 2 * 1201$. There are no 
structural differences between IBDV-8 and IBDV-12 which obviously account for this difference. The protective IBDV8 peptide is located in the linker region between the $\mathrm{P}$ and $\mathrm{S}$ domains of VP2, while the non-protective binding CB12IBDV-12 epitope is located deep in the S domain (Lee et al. 2006) and both peptides are well conserved (indeed identical in a wide variety of IBDV sequences, including strain 52/70, accession number BAA00745; strain $\mathrm{Cu} 1$, BAA00740; strain STC, BAA00391; strain E/DEL, CAA38637; strain 23/82, Z21971; strain CT, CAC35470; strain UK661, CAC60256; strain 88180, CAJ34339; isolate 903/78, AFI55462; isolate SP8, AFN80509). One explanation might be that there is a hole in the $\mathrm{T}$ cell repertoire due to negative selection in the thymus (as has been reported in mammals, see for example Wölfl et al. 2008).

The previous work (Shaw and Davison 2000) used our motifs to predict the peptides for the dominantly expressed class I molecule BF2*0401 from line C-B4 and concluded in discussion that there were no peptides that would bind, but nevertheless found that fp-IBD1 conferred the same level of protection to line C-B4 as line C-B12. One potential explanation is that another genetic locus in C-B4 is responsible for the protection, but that seems unlikely since C-B4 and C-B12 chickens are taken (as individuals or as annual sublines) from a C line flock, and so all non-MHC genes should segregate freely between the lines. Another potential explanation is that the response is due to the minor gene $\mathrm{BF} 1 * 0401$, but this gene has virtually undetectable expression at the level of RNA, protein and antigenic peptide. Therefore, the most likely explanation for the response of C-B4 is that the previous work used a very stringent peptide motif (octamers with Asp2, Asp5 and Glu8, as we published in Kaufman et al. 1995), but in fact the motif can be somewhat wider (Wallny et al. 2006). The motif and even individual peptides show that Glu is also found at positions 2 and 5 , and certain hydrophobic amino acids found at a low level at position 8. Moreover, some peptides may be longer, and there may be C-terminal overhangs, as we found for B12 and other haplotypes. In fact, this more relaxed motif does indeed predict 4 peptides from the VP2 in fp-IBD1.

These results are all in accord with the concept of a minimal essential MHC (Kaufman et al. 1995, 1999a, b; Kaufman 2008), in which the structural organisation of the chicken MHC (compared to most mammals) has striking effects on function. We have previously shown that properties of the single dominantly expressed class I molecule can explain the responses of experimental chicken lines to RSV and MDV (Wallny et al. 2006; Koch et al. 2007), and the results in this paper extend this concept from viral pathogens to viral vaccines.

Moreover, IBDV continues to be a serious threat to commercial chickens, with both antigenic variation and increase in virulence reported (reviewed in Ingrao et al.
2013; Mahgoub et al. 2012; Müller et al. 2003, 2012; Schat and Skinner 2008; van den Berg 2000). While the poultry industry generally controls IBDV through inactivated vaccines that work through class II molecules (which also show the phenomenon of MHC-determined differences in response), some attenuated viral vaccines are used, particularly in ovo (reviewed in Müller et al. 2012). The likelihood that some individual chickens remain poorly protected after either form of vaccination is an unsolved problem. Given that the MHC of many, if not most, non-mammalian vertebrates have features first discovered in chickens (reviewed in Kaufman 1999, 2008), it is likely that this is also a problem in other important contexts, for instance vaccination in some commercial fish (Grimholt et al. 2003) or resistance to citrid fungi in amphibians (Savage and Zamudio 2011).

Acknowledgments We thank Drs. Hannah Siddle and Clive Tregaskes for critical reading of the manuscript, and the Biotechnology and Biological Sciences Research Council (BBSRC core funding to the Institute for Animal Health), Department of Food, Environment and Rural Affairs (DEFRA project grant 0709 to TFD) and the Wellcome Trust (programme grant 089305 to JK) for support.

Open Access This article is distributed under the terms of the Creative Commons Attribution License which permits any use, distribution, and reproduction in any medium, provided the original author(s) and the source are credited.

\section{References}

Afanassieff M, Goto RM, Ha J, Sherman MA, Zhong L, Auffray C, Coudert F, Zoorob R, Miller MM (2001) At least one class I gene in restriction fragment pattern-Y (Rfp-Y), the second MHC gene cluster in the chicken, is transcribed, polymorphic, and shows divergent specialization in antigen binding region. J Immunol 166:3324-3333

Anonymous (1991) GCG Users Guide. Genetics Computer Group, Madison, WI

Bayliss CD, Peters RW, Cook JK, Reece RL, Howes K, Binns MM, Boursnell M (1991) A recombinant fowlpox virus that expresses the VP2 antigen of infectious bursal disease virus induces protection against mortality caused by the virus. Arch Virol 120:193-205

Belov K, Sanderson CE, Deakin JE, Wong ES, Assange D, McColl KA, Gout A, de Bono B, Barrow AD, Speed TP, Trowsdale J, Papenfuss AT (2007) Characterization of the opossum immune genome provides insights into the evolution of the mammalian immune system. Genome Res 17:982-991

Briles WE, Goto RM, Auffray C, Miller MM (1993) A polymorphic system related to but genetically independent of the chicken major histocompatibility complex. Immunogenetics 37:408-414

Bullock TN, Colella TA, Engelhard VH (2000) The density of peptides displayed by dendritic cells affects immune responses to human tyrosinase and gp100 in HLA-A2 transgenic mice. J Immunol 164:2354-2361

Butter C, Sturman TD, Baaten BJ, Davison TF (2003) Protection from infectious bursal disease virus (IBDV)-induced immunosuppression by immunization with a fowlpox recombinant containing IBDV-VP2. Avian Pathol 32:597-604

Butter C, Staines K, Baaten B, Smith L, Davison TF (2007) Route of challenge is critical in determining the clinical outcome of 
infection with a very virulent oncogenic herpesvirus, Marek's disease virus. Avian Pathol 36:93-99

Delany ME, Robinson CM, Goto RM, Miller MM (2009) Architecture and organization of chicken microchromosome 16: order of the NOR, MHC-Y, and MHC-B subregions. J Hered 100:507-514

Grimholt U, Larsen S, Nordmo R, Midtlyng P, Kjoeglum S, Storset A, Saebo S, Stet RJ (2003) MHC polymorphism and disease resistance in Atlantic salmon (Salmo salar); facing pathogens with single expressed major histocompatibility class I and class II loci. Immunogenetics 55:210-219

Guillemot F, Billault A, Pourquié O, Béhar G, Chaussé AM, Zoorob R, Kreibich G, Auffray C (1988) A molecular map of the chicken major histocompatibility complex: the class II beta genes are closely linked to the class I genes and the nucleolar organizer. EMBO J 7:2775-2785

Hofmann A, Plachy J, Hunt L, Kaufman J (2003) Hala K (2003) v-src oncogene-specific carboxy-terminal peptide is immunoprotective against Rous sarcoma growth in chickens with MHC class I allele B-F12. Vaccine 21:4694-4699

Hou Y, Guo Y, Wu C, Shen N, Jiang Y, Wang J (2012) Prediction and identification of $\mathrm{T}$ cell epitopes in the $\mathrm{H} 5 \mathrm{~N} 1$ influenza virus nucleoprotein in chicken. PLoS One 7:e39344

Ingrao F, Rauw F, Lambrecht B, van den Berg T (2013) Infectious Bursal disease: a complex host-pathogen interaction. Dev Comp Immunol. doi: 10.1016/j.dci.2013.03.017, PubMed PMID: 23567344

Jacob JP, Milne S, Beck S, Kaufman J (2000) The major and a minor class II $\beta$-chain (B-LB ) gene flank the Tapasin gene in the B-F / $\mathrm{B}-\mathrm{L}$ region of the chicken major histocompatibility complex. Immunogenetics 51:138-147

Kaufman J (1999) Co-evolving genes in MHC haplotypes: the "rule" for nonmammalian vertebrates? Immunogenetics 50:228-236

Kaufman J (2008) The avian MHC. In: Davison T, Kaspers B, Schat K (eds) The immunology of birds. Elsevier, London, pp 159-182

Kaufman J (2010) Evolution of the adaptive immune system of the jawed vertebrates. In: Kaufmann S, Rouse B, Sachs D (eds) The immune response to infection. ASM Press, Washington, DC, pp 41-55

Kaufman J, Völk H, Wallny H-J (1995) A "minimal essential Mhc" and an "unrecognized Mhc": two extremes in selection for polymorphism. Immunol Rev 143:63-88

Kaufman J, Milne S, Göbel TW, Walker BA, Jacob JP, Auffray C, Zoorob R, Beck S (1999a) The chicken B locus is a minimal essential major histocompatibility complex. Nature 401:923-925

Kaufman J, Jacob J, Shaw I, Walker B, Milne S, Beck S, Salomonsen J (1999b) Gene organisation determines evolution of function in the chicken MHC. Immunol Rev 167:101-117

Khatib HE, Genislav LB, Crittenden BN, Soller M (1993) Sequencetagged microsatellite sites as markers in chicken reference and resource populations. Anim Genet 24:355-362

Koch M, Camp S, Collen T, Avila D, Salomonsen J, Wallny HJ, van Hateren A, Hunt L, Jacob JP, Johnston F, Marston DA, Shaw I, Dunbar PR, Cerundolo V, Jones EY, Kaufman J (2007) Structures of an MHC class I molecule from B21 chickens illustrate promiscuous peptide binding. Immunity 27:885-899

Lee CC, Ko TP, Chou CC, Yoshimura M, Doong SR, Wang MY, Wang AH (2006) Crystal structure of infectious bursal disease virus VP2 subviral particle at 2.6 A resolution: implications in virion assembly and immunogenicity. J Struct Biol 155:74-86

Mahgoub HA et al (2012) An overview of infectious bursal disease. Arch Virol 157(11):2047-2057

Maruoka T, Tanabe H, Chiba M, Kasahara M (2005) Chicken CD1 genes are located in the MHC: CD1 and endothelial protein $\mathrm{C}$ receptor genes constitute a distinct subfamily of class-I-like genes that predates the emergence of mammals. Immunogenetics 57:590-600

Miller MM, Goto R, Bernot A, Zoorob R, Auffray C, Bumstead N, Briles WE (1994a) Two Mhc class I and two Mhc class II genes map to the chicken Rfp-Y system outside the B complex. Proc Natl Acad Sci U S A 91:4397-4401

Miller MM, Goto R, Zoorob R, Auffray C, Briles WE (1994b) Regions of homology shared by Rfp-Y and major histocompatibility B complex genes. Immunogenetics 39:71-73

Miller MM, Goto RM, Taylor RL Jr, Zoorob R, Auffray C, Briles RW, Briles WE, Bloom SE (1996) Assignment of Rfp-Y to the chicken major histocompatibility complex/NOR microchromosome and evidence for high-frequency recombination associated with the nucleolar organizer region. Proc Natl Acad Sci U S A 93:3958-3962

Miller MM, Wang C, Parisini E, Coletta RD, Goto RM, Lee SY, Barral DC, Townes M, Roura-Mir C, Ford HL, Brenner MB, Dascher CC (2005) Characterization of two avian MHC-like genes reveals an ancient origin of the CD1 family. Proc Natl Acad Sci U S A 102:8674-8679

Moody A, Sellers S, Bumstead N (2000) Measuring infectious bursal disease virus RNA in blood by multiplex real-time quantitative RT-PCR. J Virol Methods 85:55-64

Müller H, Islam MR, Raue R (2003) Research on infectious bursal disease - the past, the present and the future. Vet Microbiol 97:153-165

Müller H, Mundt E, Eterradossi N, Islam MR (2012) Current status of vaccines against infectious bursal disease. Avian Pathol 41:133-139

Reemers SS, van Haarlem DA, Sijts AJ, Vervelde L, Jansen CA (2012) Identification of novel avian influenza virus derived CD8+ T-cell epitopes. PLoS One 7:e31953

Rogers SL, Kaufman J (2008) High allelic polymorphism, moderate sequence diversity and diversifying selection for B-NK but not Blec, the pair of lectin-like receptor genes in the chicken MHC. Immunogenetics 60:461-475

Rogers SL, Göbel TW, Viertlboeck BC, Milne S, Beck S, Kaufman J (2005) Characterization of the chicken C-type lectin-like receptors B-NK and B-lec suggests that the NK complex and the MHC share a common ancestral region. J Immunol 174:3475-3483

Ruby T, Bed'Hom B, Wittzell H, Morin V, Oudin A, Zoorob R (2005) Characterisation of a cluster of TRIM-B30.2 genes in the chicken MHC B locus. Immunogenetics 57:116-128

Salomonsen J, Marston D, Avila D, Bumstead N, Johansson B, JuulMadsen H, Olesen GD, Riegert P, Skjødt K, Vainio O, Wiles MV, Kaufman J (2003) The properties of the single chicken MHC classical class II alpha chain (B-LA) gene indicate an ancient origin for the DR/E-like isotype of class II molecules. Immunogenetics 55:605-614

Salomonsen J, Sørensen MR, Marston DA, Rogers SL, Collen T, van Hateren A, Smith AL, Beal RK, Skjødt K, Kaufman J (2005) Two $\mathrm{CD} 1$ genes map to the chicken $\mathrm{MHC}$, indicating that $\mathrm{CD} 1$ genes are ancient and likely to have been present in the primordial MHC. Proc Natl Acad Sci U S A 102:8668-8673

Savage AE, Zamudio KR (2011) MHC genotypes associate with resistance to a frog-killing fungus. Proc Natl Acad Sci U S A 108:16705-16710

Schat KA, Skinner MA (2008) Avian immunosuppressive diseases and immune evasion. In: Davison T, Kaspers B, Schat K (eds) The immunology of birds. Elsevier, London, pp 299-322

Shaw I, Davison TF (2000) Protection from IBDV-induced bursal damage by a recombinant fowlpox vaccine, fpIBD1, is dependent on the titre of challenge virus and chicken genotype. Vaccine 18:3230-3241

Shaw I, Powell TJ, Marston DA, Baker K, van Hateren A, Riegert P, Wiles MV, Milne S, Beck S, Kaufman J (2007) Different evolutionary histories of the two classical class I genes BF1 and BF2 illustrate drift and selection within the stable MHC haplotypes of chickens. J Immunol 178:5744-5752

Shiina T, Briles WE, Goto RM, Hosomichi K, Yanagiya K, Shimizu S, Inoko H, Miller MM (2007) Extended gene map reveals tripartite motif, C-type lectin, and Ig superfamily type genes within a 
subregion of the chicken MHC-B affecting infectious disease. J Immunol 178:7162-7172

Skjødt K, Welinder KG, Crone M, Verland S, Salomonsen J, Simonsen $M$ (1986) Isolation and characterization of chicken and turkey beta 2-microglobulin. Mol Immunol 23:1301-1309

Solinhac R, Leroux S, Galkina S, Chazara O, Feve K, Vignoles F, Morisson M, Derjusheva S, Bed'hom B, Vignal A, Fillon V, Pitel F (2010) Integrative mapping analysis of chicken microchromosome 16 organization. BMC Genomics 11:616

Staines K, Young JR, Butter C (2013) Expression of chicken DEC205 reflects the unique structure and function of the avian immune system. PLoS One 8:e51799

van den Berg TP, Eterradossi N, Toquin D, Meulemans G (2000) Infectious bursal disease (Gumboro disease). Rev Sci Tech 19:509-543

Van Loon AAWM, Lutticken D, Snyder DB (1994) Rapid quantification of infectious bursal disease (IBD) challenge, field or vaccine virus strains. Proceedings of the International Symposium on Infectious Bursal Disease and Chicken Infectious Anaemia, pp. 179-187
Walker BA, Hunt LG, Sowa AK, Skjødt K, Göbel TW, Lehner PJ, Kaufman J (2011) The dominantly expressed class I molecule of the chicken MHC is explained by coevolution with the polymorphic peptide transporter (TAP) genes. Proc Natl Acad Sci U S A 108:8396-8401

Wallny HJ, Avila D, Hunt LG, Powell TJ, Riegert P, Salomonsen J, Skjødt K, Vainio O, Vilbois F, Wiles MV, Kaufman J (2006) Peptide motifs of the single dominantly expressed class I molecule explain the striking MHC-determined response to Rous sarcoma virus in chickens. Proc Natl Acad Sci U S A 103:1434-1439

Williams AE, Davison TF (2010) Enhanced immunopathology induced by very virulent infectious bursal disease virus. Avian Path 34:4-14

Wölfl M, Rutebemberwa A, Mosbruger T, Mao Q, Li HM, Netski D, Ray SC, Pardoll D, Sidney J, Sette A, Allen T, Kuntzen T, Kavanagh DG, Kuball J, Greenberg PD, Cox AL (2008) Hepatitis $\mathrm{C}$ virus immune escape via exploitation of a hole in the $\mathrm{T}$ cell repertoire. J Immunol 181:6435-6446 